\title{
Effects of hot and cold smoking processes on organoleptic properties, yield and composition of matrinxa fillet
}

\author{
Maria Luiza Rodrigues de Souza Franco ${ }^{1}$, Elisabete Maria Macedo Viegas ${ }^{2}$, Sérgio \\ Nascimento Kronka ${ }^{3}$, Rose Meire Vidotti ${ }^{2}$, Marcelo Assano ${ }^{2}$, Eliane Gasparino ${ }^{1}$
}

\footnotetext{
${ }^{1}$ Departamento de Zootecnia - Universidade Estadual de Maringá. Av. Colombo 5790, CEP: 87020-900, Maringá - PR, Brasil.

${ }^{2}$ CAUNESP/Universidade Estadual Paulista - Jaboticabal. Via de Acesso Prof. Paulo Donato Castellane, s/n, km 5. CEP:1488-900, Jaboticabal - SP, Brasil.

${ }^{3}$ Departamento de Ciências Exatas - Universidade Estadual Paulista - Jaboticabal. Via de Acesso Prof. Paulo Donato Castellane, s/n, km 5, CEP:1488-900, Jaboticabal - SP, Brasil. Pesquisador Científico do CNPq.
}

ABSTRACT - The effects of hot $\left(45-90^{\circ} \mathrm{C} / 5\right.$ hours $)$ and cold $\left(27-45^{\circ} \mathrm{C} / 10\right.$ hours $)$ smoking processes on the organoleptic properties, yield and composition of matrinxa (Brycon cephalus) fillets are evaluated. No significant differences were observed for fillet yield in both non-smoked and smoked fillets. Smoking process losses were significantly higher for hot smoked (19.37\%) when compared to cold smoked (17.08\%). Smoking process reduced moisture (in natura $=72.91 \%$, for hot $=58.51 \%$ and cold $=59.68 \%$ ) and increased crude protein, lipid and ash contents. However, there was a significant difference only for protein level between hot smoked (28.07\%) and cold smoked (27.14\%). Cold smoked process resulted in better fillet appearance and color, while hot smoked presented superior flavor, salt content and general acceptance. Aroma and texture did not differ significantly among processes. Therefore, hot smoking process shows the best results for organoleptic properties and protein levels.

Key Words: Brycon cephalus, composition smoking, fish, sensory attributes

\section{Efeitos do processo de defumação a quente e a frio sobre as propriedades organolépticas, o rendimento e a composição de filé de matrinxã}

\begin{abstract}
RESUMO - Foi avaliado o efeito do processo de defumação a quente (45-90 ${ }^{\circ} \mathrm{C} / 5$ horas) e a frio (27-45 ${ }^{\circ} \mathrm{C} / 10$ horas) nas propriedades organolépticas, no rendimento e na composição dos filés de matrinxã (Brycon cephalus). Não houve diferença significativa no rendimento de filés defumados e não-defumados. As perdas no processo de defumação foram significativamente maiores para defumação a quente (19,37\%) em comparação à defumação a frio (17,08\%). O processo de defumação reduziu a umidade (in natura $=72,91 \%$; defumado a quente $=58,51 \%$; e defumado a frio $=59,68 \%$ ) e aumentou os teores de proteína bruta, lipídios e cinzas. Houve diferença significativa somente nos teores de proteína no defumado a quente (28,07\%) e defumado a frio (27,14\%). O processo a frio resultou em melhor aparência e cor de filé, enquanto o processo a quente melhorou o sabor, o teor de sal e a aparência geral. O aroma e a textura não diferiram significativamente entre os processos. O processo de defumação a quente melhora as propriedades organolépticas e os níveis de proteína do filé de matrinxã.
\end{abstract}

Palavras-chave: atributos sensoriais, Brycon cephalus, composição da defumação, peixe

\section{Introduction}

Matrinxã (Brycon cephalus), an indigenous fish species from the Amazon Basin, is omnivore, feeding on fruits, seeds, insects and small fishes found in the environment (Goulding, 1980). It is a very promising species of great economical importance in fish culture (Fosse, 1998). In Brazil, this culture is increasing due to sports fishing (Scorvo Filho et al., 1998), great potential, high market value and easy to extract the fillet.

The texture, color and flavor of fish meat are sensorial characteristics evaluated by the consumer and, therefore they are important features for fillet processing. The presence of intra-muscular " $Y$ " shaped bones has been a problem for commercialization. Since after the smoking process the bones come off easily, this fact may be advantageous for the species.

Smoking is a preservation technique that has been used since ancient times; however, due to modern refrigeration systems smoking has become rare as a conservation method. Currently, it is employed for very particular characteristics such as sensorial qualities and excellent acceptability (aroma, color and flavor). According to Rora et al. (1998), approximately 40 to $50 \%$ of the Atlantic salmon (Salmo

Received September 22, 2008 and accepted June 16, 2009

Corresponding author:m/rsouza@uem.br 
salar) production reaches the market as a cold smoked product. However, in the context of world production of fillet (Nunes, 1999) only 2\% undergoes smoking process. This type of smoked product in Brazil is restricted and can not compete with imported smoked products. The market for smoked fish, regardless of their species and cut, in several towns of the south and southern regions is around 3\% (Macedo-Viegas et al., 2000), but may reach higher rates if duly explored.

Smoking process characteristics are important to obtain high quality products with good acceptance. Weather, temperature, sodium chloride levels, drying, timing for smoke application and type of sawdust are factors that contribute for the success of the process. There are several smoking methods such as hot, cold, liquid and electrostatic (Goncalves \& Prentice-Hernandez, 1999; Nunes, 1999). Cold smoking process includes three stages: salting, drying and smoking itself that should be conducted at temperatures lower than $30^{\circ} \mathrm{C}$ (Sigurgisladottir et al., 2000).

Hassan (1998) reports that different types of products can be obtained from smoking fish and the process of choice depends primarily on the species and region preferences for a particular product.

Current analysis evaluates the effect of hot and cold smoking processes of matrinxa fillets (Brycon cephalus) on organoleptic properties, composition, yields and losses occurred during processing.

\section{Material and Methods}

The experiment was carried out at the Centro de Aquicultura, UNESP (CAUNESP), Jaboticabal, SP.

Forty-six matrinxas (Brycon cephalus), with an average weight of $751.9 \mathrm{~g}$, a standard length $32.8 \mathrm{~cm}$ and $9.9 \mathrm{~cm}$ height were captured and killed by thermal shock (isothermal boxes filled with ground ice and water, 1:1).

Weights of fillet with skin and smoked fillet with skin were determined and yields were calculated. Filleting was performed by only one person. Fish dorsolateral muscle (hypaxial and epaxial) was removed through a cut along the backbone from the head toward the tail. Each fillet was identified with a metallic tag, and then smoked.

The smoking method, based on Machado (1984), Evangelista (1994), Oetterer (1995), Gonçalvez and PrenticeHernández (1998a), Souza (1998) and Nunes (1999), is shown in the flowchart below (Figure 1). The methodology has been the same for the cold and hot processes, with different temperatures and smoking times.

After weighing, fish were cleaned and filleted. They were washed under running water to clean superficial mucus and impurities, then they were scaled, eviscerated and filleted. This was followed by another washing to remove remained blood to avoid deterioration that could affect the fillet's quality. The fillets were then weighed.

Salting was conducted by a moist method by which fillets were immersed in 30\% refined salt solution, ratio 2:1 brine to fillet (volume/weight), for 30 minutes. Brine temperature was decreased by adding ice. After salting, the fillets were washed in running water to eliminate excess of salt from the surface and avoid formation of crystals at the end of the smoking process.

Fillets were then hanged in an airy room for approximately 1 hour in order to drain off water excess and obtain a faster and more uniform drying.

Fillets were partially dried in the smoking chamber, with temperatures ranging from 30 to $35^{\circ} \mathrm{C}$, for 50 minutes. A superficial drying and the formation of a protective skin over the cut surface (coagulated proteins) that gave the fillet a golden color during the smoking was employed. In addition, the drying process makes smoke penetration easier and allows partial meat exudation. The latter factor provides a better appearance to the final product.

Smoking itself was conducted by two techniques, a hot and a cold one. Hot smoking was performed at temperatures ranging from 45 and $90^{\circ} \mathrm{C}$, for about 5 hours. Cold smoking was carried out at temperatures from 27 to $45^{\circ} \mathrm{C}$, for about 10 hours.

Smoking process was conducted on a $100 \mathrm{~kg}$-stainless steel smoker, and indeed a smoke generator outside to the smoking chamber.

Whereas combustion material for smoke production originated from non-resin wood and sawdust from pink eucalyptus, gas was the heat source used to maintain the temperature.

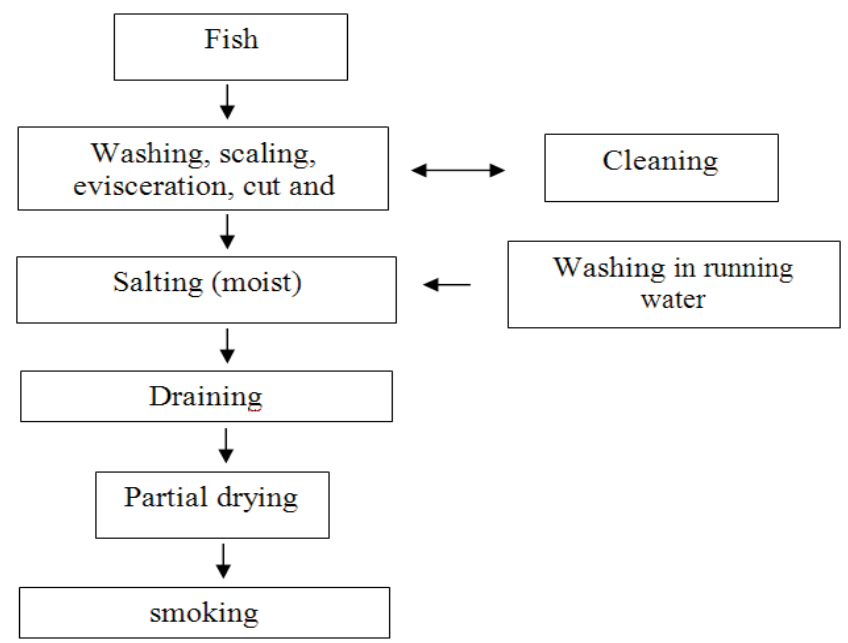

Figure 1 - Flow chart of smoking process of matrinxã. 
The last stage comprises cleaning, cooling down, packaging and storing under refrigeration. The smoked fillets were taken from the smoker and cleaned at the surface to remove ashes and to cool down before packaging. This procedure avoids mold formation on the surface of the smoked product.

Fillets were then wrapped in plastic film, placed in polyethylene plastic bags and stored in a freezer at $-18^{\circ} \mathrm{C}$ for further sensorial analysis and composition.

Smoking process yield was determined by using 20 fish for each treatment. Calculation of filleting, smoking yields and losses of both hot and cold processes were based on fish total weight.

Six fillet samples of each type, hot and cold, smoked and non-smoked, were frozen at $-18^{\circ} \mathrm{C}$ for composition analysis. The samples were minced in a food multiprocessor to obtain a homogeneous pulp. Small portions of this pulp were used to determine the composition (moisture, protein, lipids and ash), according to AOAC official methodology (1995).

The sensory attributes were evaluated by a non-trained panel (37). Samples of standard weight and fillet cutting (25g) were stored under refrigeration, 24 hours after the smoking process; they were wrapped in aluminum foil and heated in an electric oven at $50^{\circ} \mathrm{C}$. The panel received the samples randomly, together with a fill-out form for sensory analysis. Flavor, odor, appearance (color), texture and general acceptance were evaluated in a hedonic scale of 9 points (from $9=$ Iliked it very much to $1=$ I disliked it very much) (Figure 2).

Variables were analyzed according to the following mathematicalmodel: $Y_{i j}=\mu+D i+e_{i j}$, where $Y_{i j}=$ observation referring to the fish $\mathrm{j}$, for smoking process $\mathrm{i}, \mu=$ common constant, $\mathrm{D}_{\mathrm{i}}=$ effect of smoking process $\mathrm{i},(\mathrm{i}=1 ; 2), \mathrm{e}_{\mathrm{ij}}$ = random error associated with observation $\mathrm{ij}$.

The same mathematical model was used for composition analysis with the inclusion of the smoking process effect (control, non-smoked fillet). As for sensorial analysis, the block effect (panel) was included.

Yields, losses, sensorial analysis and fillet composition results were submitted to variance analysis and averages were compared by Tukey test, at 5\% probability (Banzatto \& Kronka, 1995).

\section{Results and Discussion}

Non-smoked fillet weight and yield were not significantly different (Table 1). According to Tessitore et al. (2009), tilapia species in the range of slaughter weight from 250 to 600 g presented steaks ranging from 239.95 to $292.80 \mathrm{~g}$ and yield ranging from 33.23 to $35.41 \%$, values lower than those of matrinxã obtained in this work.

Average yield of smoked fillet was 33.84 and $34.55 \%$, for hot and cold processes, respectively, based on total weight. There were no significant differences $(\mathrm{P}>0.05)$ for losses occurred during filleting, 46.8 and $48.37 \%$, respectively for fillet submitted to hot and cold smoking processes. This result may be attributed to the fact that the fish were in the same weight class, the same filleting method was applied and all fish were filleted by the same person. Smoking method affected weight losses of smoked fillet, the hot process loss was significantly higher (19.37\%) than the cold one (17.08\%) (Table 1). According to Sigurgisladottir et al. (2000), the weight loss is due to dehydration during smoking and it varies between 10 and 25\% depending on several factors, such as origin of raw material, final product characteristics and parameters used in the process, time and temperature. Comparison of total losses during hot and cold smoking processes (filleting and smoking) showed no significant differences (Figure 2).

Sigurgisladottir et al. (2000) reported that raw material is highly important for yield and quality of the final product. Rora et al. (1999) also observed that type of raw material, manual processing method, brine type and quantity, and smoking conditions (temperature, moisture, air flow rate, drying) are determinant factors on the weight variation during smoking. The same authors evaluated processing yield, color and sensorial quality of Atlantic salmon (Salmo salar), with variation of only the raw material (fish weighing between 3 and $7 \mathrm{~kg}$, with average weight from 3.4 to $5.2 \mathrm{~kg}$ ). Smoking conditions were constant. When fish were filleted, the backbone and head caused higher losses

Table 1 - Average values of fillet weight and yield, losses occurred during the smoking process of matrinxã (Brycon cephalus)

\begin{tabular}{|c|c|c|c|c|c|c|c|}
\hline \multirow[b]{2}{*}{ Processing method } & \multirow[b]{2}{*}{ Non-smoked } & \multicolumn{2}{|c|}{ Fillet weight (g) } & \multicolumn{2}{|c|}{ Fillet yield (\%) } & \multicolumn{2}{|c|}{ Process losses (\%) } \\
\hline & & Smoked & Non-smoked & Smoked & Filleting & Smoking & Total \\
\hline Hot smoked & 397.66 & 252.87 & 53.21 & 33.84 & 46.80 & 19.37 & 66.17 \\
\hline Cold smoked & 390.57 & 261.33 & 51.63 & 34.55 & 48.37 & 17.08 & 65.45 \\
\hline $\mathrm{F}$ test & $0.17^{\mathrm{ns}}$ & $0.48^{\mathrm{ns}}$ & $2.73^{\mathrm{ns}}$ & $0.62^{\mathrm{ns}}$ & $2.73^{\mathrm{ns}}$ & $17.26 * *$ & $4.03^{\mathrm{ns}}$ \\
\hline CV (\%) & 13.72 & 15.03 & 6.10 & 7.78 & 6.71 & 9.63 & 0.62 \\
\hline
\end{tabular}

${ }^{n s}$ Non significant $(\mathrm{P}>0.05)$; ** Significant $(\mathrm{P}<0.01)$. 


\begin{tabular}{|c|c|c|c|}
\hline \multicolumn{2}{|c|}{ Hot smoking process } & \multicolumn{2}{|c|}{ Cold smoking process } \\
\hline & $\begin{array}{l}\text { Body weight } \\
747.34 \mathrm{~g}-(100 \%)\end{array}$ & $\begin{array}{l}\text { Body weight } \\
756.43 \mathrm{~g}-(100 \%)\end{array}$ & \\
\hline \multirow[t]{2}{*}{ Filleting losses - $46.80 \%$} & $\downarrow$ & $\downarrow$ & Filleting losses $-48.37 \%$ \\
\hline & $\begin{array}{l}\text { Fillet weight with skin } \\
\text { non smoked } \\
397.66 \mathrm{~g}-(53.21 \%)\end{array}$ & $\begin{array}{l}\text { Fillet weight with skin } \\
\text { non smoked } \\
390.57 \mathrm{~g}-(51.63 \%)\end{array}$ & \\
\hline \multirow[t]{2}{*}{ Smoking losses $-19.37 \%$} & $\downarrow$ & $\downarrow$ & \multirow{2}{*}{ Smoking losses $-17.08 \%$} \\
\hline & $\begin{array}{l}\text { Fillet weight with skin } \\
\text { smoked } \\
252.87 \mathrm{~g}-(33.84 \%)\end{array}$ & $\begin{array}{l}\text { Fillet weight with skin } \\
\text { smoked } \\
261.33 \mathrm{~g}-(34.55 \%)\end{array}$ & \\
\hline Total losses $-66.17 \%$ & & & Total losses $-66.45 \%$ \\
\hline
\end{tabular}

Figure 2 - Yields and losses of filleting and hot and cold smoking processes.

(22.5\%) compared to losses occurred after trimming (13.2\%) and smoking (8.1\%). However, proportional fat deposited dorsally and on the peritonea was higher for heavier fish. Therefore, the losses occurred during fillet trimming were caused by fat increase. The authors reported that the losses occurred during smoking were influenced by the amount of fat and fillet water content.

In current experiment, only smoking time and temperature changed, with higher smoking losses. Smoked fillet yield for matrinxã (33.84 and 34.55\%) was lower when compared to Atlantic salmon (61.9\%). This may be attributed to the species (anatomic shape, fillet thickness and composition), weight, smoking temperature and time. Santos et al. (2007) analyzed fillet yield in natura and smoked fillet (with and without rosemary) of the Nile tilapia. The authors register fillet yield at 38.59\% and $37.71 \%$, and smoked fillet with or without rosemary at $20.81 \%$ and $25.58 \%$, respectively. In fact, rates were lower than those in current experiment with matrinxã.

The cut executed on the fish also influenced yield. According to Pereira (1993), smoking yield for pacu (Piaractus mesopotamicus) was 39.3\%, 38.6\% and 60.9\% respectively for slice, butterfly and ventral cuts, respectively.

Fillet composition is of great technological importance since it affects yield, flavor, texture and fat oxidation stability. Food, age, weight, seasonal variation and physiological phase also influence composition (ContrerasGuzman, 1994). Therefore, those factors that might affect analysis could be avoided. Fish were of the same weight class, origin and fed on the same diet (Table 2).

There was significant difference $(\mathrm{P}<0.01)$ among smoked and non-smoked fillets (Table 2). Smoking process reduced moisture content from $72.91 \%$ to $58.51 \%$ and $59.68 \%$, for hot and cold processes, respectively. There was an increase in protein, lipid and ash contents (Table 2). However, the smoking process affected only protein content; $28.07 \%$ for hot was significantly higher $(\mathrm{P}<0.01)$ than $27.14 \%$ for cold process. Moisture contents for whole matrinxa are reported at $60.62 \%$ and $62.34 \%$ for 400 and 700 g body weight (Macedo-Viegas et al., 2000), respectively, In fact these values are lower than the results obtained in this work with matrinxa fillet.

Increase of ash content in smoked fillets (hot $=3.28 \%$ and cold $=3.47 \%$ ) is probably due to absorption of sodium chloride by the muscle during salting. Analyzing the effect of weight classes on body composition of matrinxa, MacedoViegas et al. (2000) reported variation ranging from 1.81 to $3.01 \%$ in ash levels. It is the highest value observed in the heaviest class (601-700 g).

Regarded to fat content, Contreras-Guzmän (1994) reported the combination of fat and protein contents with the formations of several groups (categories). According to this classification, matrinxa lies at category D, or rather,

Table 2 - Composition of non-smoked and smoked (hot and cold) matrinxã fillet (Brycon cephalus)

\begin{tabular}{lcccc}
\hline Fillet & \multicolumn{4}{c}{ Composition } \\
\cline { 2 - 5 } & $\begin{array}{c}\text { Moisture } \\
(\%)\end{array}$ & $\begin{array}{c}\text { Crude } \\
\text { protein }(\%)\end{array}$ & $\begin{array}{c}\text { Ash } \\
(\%)\end{array}$ & $\begin{array}{c}\text { Lipids } \\
(\%)\end{array}$ \\
\hline Non-smoked & $72.91 \mathrm{a}$ & $20.07 \mathrm{c}$ & $1.25 \mathrm{~b}$ & $3.37 \mathrm{~b}$ \\
Hot smoked & $58.51 \mathrm{~b}$ & $28.07 \mathrm{a}$ & $3.28 \mathrm{a}$ & $8.09 \mathrm{a}$ \\
Cold smoked & $59.68 \mathrm{~b}$ & $27.14 \mathrm{~b}$ & $3.47 \mathrm{a}$ & $7.76 \mathrm{a}$ \\
F test & $336.37^{* *}$ & $365.92^{* *}$ & $265.07 * *$ & $90.04 * *$ \\
CV $(\%)$ & 1.73 & 2.23 & 6.94 & 10.63 \\
\hline
\end{tabular}

In each column average followed by the same letters did not differ by Tukey test, at $5 \%$ probability.

** Significant $(\mathrm{P}<0.01)$. 
extremely high in protein level ( $>20 \%)$ and low in fat $(<5 \%)$. Lipid increase observed in smoked fillets, hot and cold, is caused by dehydration, or rather, a moisture reduction due to smoking. Fat content is very important for smoking process, in which fish, classified as fat (lipids over 10\%), are the most appropriate. Actually, fat acts as an absorbent agent of the aromatic substances present in the smoke. Solely because of this, matrinxã would not be the most indicated fish for smoking; however, the panel accepted the product well.

Matrinxã crude protein, lipids and ash levels are higher when compared to African catfish (Clarias gariepinus) values, which vary between 18.03 and $18.58 \%$; 1.51 and $3.03 \%$ and 1.09 and $1.14 \%$, respectively (Souza et al., 1999). Szenttamasy et al. (2000) reported that non-smoked and smoked pacu presented, respectively, 18.99 and 23.08\% protein, 3.79 and $2.69 \%$ lipids and 1.82 and 3.13\% ash. Macedo-Viegas et al. (2000) registered lower values of protein (13.34 to $19.05 \%$ ) for whole matrinxa, compared to values reported here for matrinxa fillet. Souza et al. (2005) reported variations in smoked fillet of the Nile tilapia between 29.67 and $30.37 \%$ crude protein, 3.49 and $3.69 \%$ lipids, 5.09 and $5.42 \%$ ash for fillets featuring between
61.00 and $61.68 \%$ humidity. Actually amount of lipids in tilapia fillets is lower than that of matrinxã, and provides a higher absorption of sodium chlorate in the salting process. This fact may be observed by the ash rate.

Fillet appearance and color submitted to cold smoking were significantly higher than the hot process, or rather, 2.68 and 2.73 respectively (Table 3 ). Aroma did not differ among treatments. There was significant difference $(\mathrm{P}<0.01)$ for fillet flavor, salt content and general acceptance. Hot smoking process values were higher than those from the cold process, 2.91, 2.83 and 2.91, compared to 2.7, 2.69 and 2.69 , respectively. Texture did not differ among treatments (hot $=2.81$ and cold $=2.64$ ). Therefore, hot smoking process presented better results for organoleptic traits.

The lowest average grades given by the panel were 6.68 for appearance and 6.47 for texture of hot and cold smoked fillet, respectively, while the highest grades were 7.97 and 7.74 , respectively for flavor and general acceptance of hot smoked fillet and color of cold smoked fillet. The average grade for general acceptance of hot smoked fillet (7.97) is similar to the average value (8.43) reported by Gonçalves \& Prentice-Hernandez (1998b) for anchovies (Pomatomus saltatrix) submitted to liquid smoking process.

Table 3 - Average grades attributed by the test panel to the sensorial traits for both smoking process of matrinxã (Brycon cephalus)

\begin{tabular}{|c|c|c|c|c|c|c|c|}
\hline \multirow{3}{*}{ Processing method } & \multicolumn{7}{|c|}{ Sensorial traits ${ }^{1}$} \\
\hline & \multicolumn{3}{|c|}{ Whole fillet } & \multicolumn{3}{|c|}{ Fillet portion } & \multirow{2}{*}{$\begin{array}{c}\text { General } \\
\text { Acceptance }\end{array}$} \\
\hline & Appearance & Aroma & Color & Flavor & Texture & Salt content & \\
\hline Hot smoked & $2.68^{1}$ & 2.73 & 2.76 & 2.91 & 2.81 & 2.83 & 2.91 \\
\hline Cold smoked & 2.85 & 2.78 & 2.87 & 2.70 & 2.64 & 2.69 & 2.69 \\
\hline $\mathrm{F}$ test & $9.58 * *$ & $0.73^{\mathrm{ns}}$ & $7.54 * *$ & $8.38^{* *}$ & $2.98^{\mathrm{ns}}$ & $5.79 * *$ & $9.94 * *$ \\
\hline CV (\%) & 8.69 & 8.65 & 5.89 & 11.30 & 15.27 & 9.16 & 10.63 \\
\hline
\end{tabular}

${ }^{1}$ Values transformed by $\sqrt{ } \mathrm{x}+0.5$

ns Non significant $(\mathrm{P}>0.05)$; ** Significant $(\mathrm{P}>0.01)$

\section{Conclusions}

The comparison of hot and cold smoking process of matrinxa fillet shows that the hot process is more appropriate because of the better organoleptic traits and the higher protein level as well. It should also be noted that the hot smoking process (5 hours) is much faster than the cold process (10 hours).

\section{References}

ASSOCIATION OF OFFICIAL ANALYTICAL CHEMISTRY AOAC. Official methods of analysis. 16.ed. Arlington: AOAC International, 1995. 1025p.
BANZATTO, D.A.; KRONKA, S.N. Experimentação agrícola. 3.ed. Jaboticabal: FUNEP, 1995. 247p.

CONTRERAS-GUZMÁN, E.S. Bioquímica de pescados e derivados. Jaboticabal: FUNEP, 1994. 409p.

EVANGELISTA, J. Tecnologia de alimentos. São Paulo: Atheneu, 1994. 652p.

FOSSE, P.J. Engorda do matrinxã (Brycon cephalus) com inclusão de feno de alfafa em rações: crescimento, pigmentação e rendimentos. 1998. 65p. Dissertation (Master in Animal Quality and Productivity) - Faculdade de Zootecnia e Engenharia de Alimentos/Universidade de São Paulo, Pirassununga.

GONÇALVES, A.A.; PRENTICE-HERNÁNDEZ, C. Fumaça líquida: uma tecnologia para defumar pescado. Boletim SBCTA, v.32, n.2, p.189-199, 1998a.

GONÇALVES, A.A.; PRENTICE-HERNÁNDEZ, C. Defumação líquida de anchova (Pomatomus saltatrix): efeito do processamento nas propriedades químicas e microbiológicas. 
Ciêncica Tecnologica de Alimentos, v.18, n.4, p.438-443, 1998b.

GONÇALVES, A. A.; PRENTICE-HERNÁNDEZ, C. Defumação líquida de anchova (Pomatomus saltatrix): estabilidade lipídica durante o processamento e o armazenamento. Revista do Instituto Adolfo Lutz, v.58, n.1, p.69-78, 1999.

GOULDING, M. The fishes and the forest: explorations in Amazonian natural history. Los Angeles: University of California Press, 1980. p.68-74.

HASSAN, I.M. Processing of smoked common carp fish and its relation to some chemical, physical and organoleptic properties. Food Chemistry, v.27, p.95-106, 1988.

MACEDO-VIEGAS, E.M.; SOUZA, R.M.L.; BACCARIN, A.E. et al. Aspectos mercadológicos de pescados e derivados em algumas cidades das regiões sul e sudeste do Brasil. Infopesca internacional, v.6, p.13-22, 2000.

MACHADO, Z.L. Tecnologia de recursos pesqueiros. Recife: Minter e Sudene, 1984. 277p.

NUNES, M.L. Defumação. In: OGAWA, M.; MAIA, E.L. (Eds.) Manual de Pesca - ciência e tecnologia do pescado. São Paulo: Varela, 1999. p.300-306.

OETTERER, M. Pescado defumado-unidades processadoras e operação de defumadores artesanais. In: SEMINÁRIO SOBRE TECNOLOGIA DE SALGA E DEFUMAÇÃO DE PESCADO, 1995. Anais... Campinas, 1995. p.18-32.

RØRA, A.M.B.; KVALE, A.; MORKORE, T. et al. Process yield, colour and sensory quality of smoked Atlantic salmon (Salmo salar) in relation to raw material characteristics. Food Research International, v.31, n.8, p.601-609, 1998.

SANTOS, L.D.; ZARA, R.F.; VISENTAINER, J.V. et al. Avaliação sensorial e rendimento de filés defumados de tilápia (Oreochromis niloticus Linnaeus, 1757) na presença de alecrim (Rosmarinus officinalis). Ciência Agrotecnica, v.31, n.2, p.406-412, 2007.

SCORVO FILHO, J.D.; MARTINS, N.B.; AYROZA, L.M.S. Piscicultura em São Paulo: custos e retornos de diferentes sistemas de produção na safra de 1996/1997. Informações Econômicas, v.28, n.3, p.41-60, 1998.

SIGURGISLADOTTIR, S.; SIGURDARDOTTIR, M.S.; TORRISSEN, O. et al. Effects of different salting and smoking processes on the microstructure, the texture and yield of Atlantic salmon (Salmo salar) fillets. Food Research International, v.33, p.847-855, 2000.

SOUZA, M.L.R.; MACEDO VIEGAS, E.M.; SOBRAL, P.J.A. et al. Efeito do peso de tilápia do Nilo (Oreochromis niloticus) sobre o rendimento e a qualidade de seus filés defumados com e sem pele. Revista Ciência e Tecnologia de Alimentos, v.25, n.1, p.51-59, 2005.

TESSITORE, A.J.A.; OLIVEIRA, L.L.S.; SARAIVA, E.P. Características morfométricas, rendimentos de carcaça, filé, vísceras e resíduos em tilápias-do-nilo em diferentes faixas de peso. Revista Brasileira de Zootecnia, v.38, n.8, p.1407-1412, 2009. 